\title{
Utjecaj bolesti na povijest - primjer epidemija
}

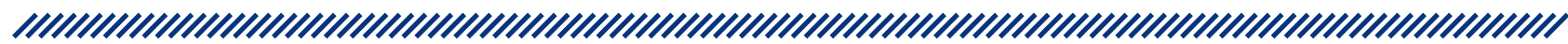

1 Jelena Barišić

1 Klinika za kirurgiju - Zavod za traumatologiju i koštanozglobnu kirurgiju, KBC Zagreb, Zagreb

\section{Sažetak}

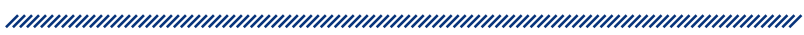

Povijest bolesti može se istraživati na različite načine. Istraživanje može ostati u striktno medicinskim okvirima i fokusirati se na oblik bolesti, pitanja prevencije, metode liječenja i drugo. Međutim, bolest nije samo medicinski fenomen zato što se njezine posljedice osjećaju na široj društvenoj razini. Stoga je važno uočiti na koji način bolest utječe na povijest.

U radu se ovaj utjecaj promatra na primjeru triju epidemija koje su u različitim povijesnim periodima poharale različita područja. Spomenuti utjecaj promatra se kroz prizmu trajanja, geografskog dosega te pretpostavke bi li povijest bila drugačija da se bolest nije dogodila.
Ključne riječi: povijest, epidemija, kuga, tifus, velike boginje, Napoleon

Datum primitka: 20.9.2018.

Datum prihvaćanja: 1.4.2019.

DOI: $10.24141 / 1 / 5 / 2 / 8$

Adresa za dopisivanje:

Jelena Barišić

A: KBC Zagreb, Kišpatićeva ul. 12, 10000 Zagreb

E-mail: jelena89barisic@gmail.com

T: +385958870370 


\section{Uvod}

O tome da je bolest bila neizbježna pratiteljica ljudi kroz prošlost nikada nije bilo spora. Bolesti su prisutne kroz cijelu povijest i ova činjenica nije prolazila nezapaženo. Pa ipak, sve donedavno promatralo ih se isključivo kao dio društvenih uvjeta u kojima su ljudi živjeli. Tek se u naše vrijeme počelo istraživati koliki je i kakav bio njihov utjecaj na sam tijek povijesti. Bilo je vrlo lako uočiti da je to doista bio slučaj. S obzirom na različite vrste bolesti i načine na koje se pojavljuju, taj se utjecaj jednako tako mogao manifestirati u različitim oblicima. Već se sama pojava bolesti kroz povijest može razvrstati primjenjujući više mjerila. Jedno bi bio doseg oboljenja, a tu se kao temeljno nameće pitanje je li bolest napala pojedinca ili širu zajednicu. U prvom se slučaju onda nameće pitanje je li riječ o psihičkoj ili somatskoj bolesti, dok bi iz drugoga proizlazio istraživački problem oko toga je li riječ o izbijanju neke epidemije ili nekoj bolesti koja je dugo prisutna na nekom području, kao što je, primjerice, slučaj s malarijom. Tada bi se metodom komparacije moglo pokazati jesu li područja gdje je malarija kroz povijest bila dulje prisutna pokazala određene razlike u razvoju u odnosu na ona gdje ove bolesti nije bilo. Ukratko, pravci su istraživanja utjecaja bolesti na povijest mnogostruki i pružaju široke mogućnosti istraživanja. Stoga je na ovome mjestu važno istaknuti nekoliko stvari povezanih s metodologijom.

\section{1. „Povijest bolesti” $\mathbf{i}$ „bolest u povijesti”}

Prva je među njima razlikovanje pojmova „povijest bolesti” u odnosu na „bolest u povijesti”. Vidljivo je kako se u prvom slučaju bolest promatra s primarno medicinskog gledišta, odnosno za istraživanje su važnija pitanja poput: kada se bolest pojavila, gdje, koliko je dugo trajala, o kojoj je točno bolesti bila riječ i slična. Drugim riječima, naglasak se u najvećoj mjeri stavlja na samu bolest, odnosno medicinski aspekt pitanja, jer često nije moguće precizno utvrditi o kojoj je točno bolesti u nekom povijesnom trenutku bila riječ. Na taj je način istraživanje bolesti često usmjereno na njezin etiološki karakter, pri čemu izostaje ikakvo opširnije smještanje njezine pojave u širi društveni kontekst.

Upravo je taj spomenuti društveni kontekst onaj temeljni okvir pisanja o „bolesti u povijesti”. Naime, umjesto isticanja medicinskog aspekta, ovdje se ključni naglasak stavlja na pitanje kako je bolest utjecala na povi- jest. Pri tom se nekada precizna medicinska narav neke bolesti i ne može utvrditi sa stopostotnom sigurnošću. Međutim, ako je nedvojbeno utvrđena njezina prisutnost u nekom periodu, svejedno se može istraživati njezin utjecaj na šire društvene prilike. Nemogućnost preciznog određivanja o kojoj je točno bolesti bila riječ bit će zastupljena i u primjerima obrađenima u ovom radu.

Dakako, ova dva različita pogleda na odnos pojmova „povijesti” i „,bolesti” ne moraju nužno stajati u suprotnosti ili se međusobno isključivati. Ipak, opravdano je pretpostaviti kako će istraživači s polja medicine biti zainteresiraniji za prvi pristup, osobito za to da utvrde točnu narav bolesti, dok će povjesničari biti skloniji tomu da bolest promatraju kao još jedan od faktora koji u nekom trenutku utječu na ljudsko društvo. Usporedba bi se mogla povući s meteorološkim prilikama ili nekim geološkim pojavama poput potresa ili erupcija vulkana. Povjesničare neće toliko zanimati precizan uzrok nekog perioda suša ili erupcije nekog vulkana, kao što, s druge strane, meteorolozi ili seizmolozi neće biti zainteresirani utvrditi je li neka suša ili erupcija posljedično utjecala na izbijanje nekakve revolucije ili rata.

\subsection{Ciljevi i hipoteze}

Osnovni je cilj ovog rada bolest promotriti upravo s ove druge točke gledišta, dakle pokazati je li bolest utjecala na povijest te osobito može li se govoriti kako je bolest promijenila tijek povijesti. Tema, naravno, nije originalna jer o njoj postoji sve brojnija literatura nastala prvenstveno u Sjedinjenim Američkim Državama ili Velikoj Britaniji. I sam pregled svih autora i tema kojima su se bavili uvelike bi povećao opseg ovog rada. Očekivano, obrađivani su primjeri dobro poznati i iz opće povijesti kao što su velike epidemije koje će se spomenuti i u ovom tekstu, a s obzirom na mjesto objavljivanja, mnogi se autori bave i utjecajem koje su bolesti imale na europsku kolonizaciju Amerike ili Afrike. Naravno, idealno bi bilo provesti originalno istraživanje koje bi ili obradilo neki povijesni primjer koji su dosadašnja istraživanja propustila ili bi obradilo neki primjer utjecaja bolesti na hrvatsku povijest. I jedno i drugo iz pozicije autorice ovog rada trenutačno je nemoguć zadatak. Osim velikog perioda i sustavnog proučavanja strane literature (za koju je rečeno da je vrlo velika), nedostaju i konkretna istraživanja provedena u Hrvatskoj. $\mathrm{Na}$ hrvatskom jeziku, osim prijevoda, i dalje je uglavnom zastupljen pristup u kojemu se piše o povijesti bolesti, odnosno više o njezinu trajanju negoli utjecaju. Dovoljno je ovdje samo spomenuti kako je djelo Bolest i povijest ${ }^{1}$ izvorno na engleskom jeziku objavljeno još 1972 ., 
dok djelo The Black Death Philippa Zielgera ${ }^{2}$ još uvijek nije prevedeno na hrvatski jezik. Stoga je kao drugi cilj postavljeno proširivanje istraživačkih vidika, odnosno predstavljanje povjesničarske metodologije u medicinskim istraživanjima. Prema tome kriteriju izabirani su i primjeri. U dva slučaja riječ je o primjerima za koje je opravdano pretpostaviti kako su na općoj razini dobro poznati i široj javnosti. Treći je izabran kao suprotnost jer na jedan jednako tako dobro poznat događaj baca potpuno drugačije svjetlo stavljajući naglasak na medicinski, umjesto na meteorološki aspekt.

Primarni naglasak bit će na utjecaju bolesti, u ovom slučaju epidemija, na povijest. U obzir će se uzeti vremenski okvir tog utjecaja, a kao primjeri poslužit će epidemije na kojima će se pokazati sličnosti i razlike. Pokušat će se dokazati da bolest $s$ jedne strane doista utječe na povijest, ali također iznijeti pretpostavka da bolest na određeni način i mijenja njezin tijek, odnosno da bi se u određenim slučajevima povijesni događaji raspleli na drugačiji način.

Prvi slučaj prezentirat će španjolsko osvajanje Srednje i Južne Amerike u 16. st. Drugi je primjer epidemija bubonske kuge u 14. st. koja je u povijest ušla pod nazivom „crna smrt”, a poharala je gotovo cijelu Europu odnijevši golem broj života. Posljednji slučaj opisat će epidemiju tifusa koja je pogodila vojsku koju je Napoleon Bonaparte 1812. poveo u napad na Rusiju. Na taj će način biti prikazana dva obrasca širenja epidemija, odnosno kako one djeluju kada pogode jedno šire područje, a kako kada ostanu ograničene na točno određenu skupinu. Po tome će se vidjeti sve sličnosti i razlike.

Kada se govori o vremenskom okviru u kojemu bolest utječe na povijest, jasno se mogu razlikovati trenutačni, tj. neposredni utjecaj bolesti i dugoročni, odnosno posredni utjecaj. U prvom slučaju riječ je o učincima koje neka epidemija ima tijekom samog svojeg trajanja i neposredno po svojem povlačenju. Tada bolest izravno djeluje na društvo jer su joj izloženi oboljeli, kao i njihovi suvremenici u neposrednom susjedstvu. Kada govorimo o dugoročnom utjecaju, tada uočavamo posljedice koje je neka epidemija ostavila i dugo nakon što je nestala iz nekog područja. Te posljedice imaju utjecaj i na one generacije koje nisu izravno bile izložene bolesti, pa čak i na ona društva koja ni na koji način nisu bila izložena konkretnoj epidemiji.

\section{Bolest i kolonizacija Amerike}

Vjerojatno najbolje poznati primjer za oba ova utjecaja predstavlja povijesni razvoj Srednje i Južne Amerike nakon susreta sa španjolskim i portugalskim kolonizatorima. Europljani su sa sobom donijeli neke zarazne bolesti poput velikih boginja (variole), vodenih kozica, ospica (male boginje) ili zaušnjaka na koje lokalno stanovništvo (Indijanci) nije imalo nikakav imunitet. Uslijedila je smrtnost širokih razmjera koja je Španjolcima omogućila brzo i lako osvajanje njihova područja. ${ }^{1} \mathrm{Na}$ ovome je primjeru jasno uočljiv trenutačan i neposredan utjecaj bolesti na povijest. lako kudikamo malobrojniji od domorodačkog stanovništva, španjolski su kolonizatori bez većih poteškoća, žrtava ili financijskog iscrpljivanja osvojili goleme prostore i udarili temelj Španjolskoj kao globalnoj velesili u idućim stoljećima. Zapravo su postojale tri epidemije, a čini se da je bila riječ o različitim bolestima. ${ }^{3}$ Prva je trajala 1519. i 1520., a bila je riječ o velikim boginjama. Zatim su uslijedile dvije epidemije (1545. - 1548. i 1576. - 1578.) čija je bolest zabilježena na lokalnom jeziku domorodaca kao cocoliztli, a bila je riječ o nekoj od bolesti iz skupine virusnih hemoragijskih groznica čiji je razvoj i širenje pospješila dugotrajna suša. ${ }^{3}$ Demografski gubici bili su ogromni, vjerojatno i najveći u sva tri primjera iz ovoga rada, o čemu svjedoči graf na slici 1.

Detaljnijom analizom jasno se zapaža i utjecaj duljeg trajanja. Naglo smanjivanje stanovništva lišilo je kolo-

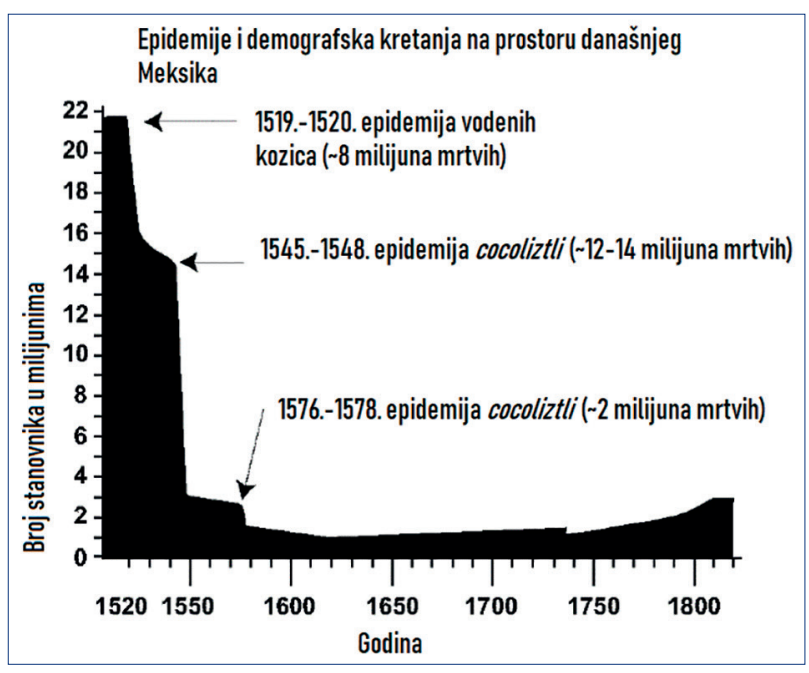

Slika 1. Grafikon s demografskim gubicima na prostoru današnjeg Meksika 
nizatore radne snage. Stoga su pribjegli dovođenju robova iz Afrike. Na taj je način promijenjena etnička slika američkog kontinenta, a tamošnji događaji odrazili su se na sudbinu brojnih afričkih plemena. Sličan se razvoj dogodio i u Sjevernoj Americi, gdje su Indijanci na istočnoj obali također u prvim susretima s britanskim i nizozemskim kolonistima pretrpjeli određene demografske gubitke. U korijenu svega stajala je bolest. ${ }^{1} \mathrm{Iz}$ današnje perspektive, sjevernoamerički Indijanci suočili su se $s$ još jednim zdravstvenim problemom. Bila je riječ o alkoholizmu, koji je također utjecao na njihovo povlačenje pred europskim doseljenicima, ali i trajno narušavao socijalne odnose.

Primjer epidemija koje su poharale domorodačko stanovništvo dviju Amerika pokazuje da su i neposredni i posredni utjecaji bolesti bili vrlo slični i, što je najvažnije, relativno ih je lako dovesti u međusobnu vezu. Dakako, u povijesti su češći primjeri gdje to nije uvijek lako moguće.

\section{3. "Crna smrt"}

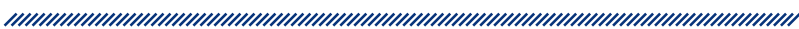

Sljedeći primjer predstavlja epidemija kuge koja je na svojem vrhuncu od 1347. do 1353. poharala najveći dio Europe, sjevernu Afriku i cijelu Aziju, a u povijest je ušla pod imenom „crna smrt”-2,4-7. Riječ je bila o situaciji kada je bubonski tip kuge, kao najčešći oblik bolesti, prešao u neuobičajeni plućni. Ovaj tip kuge napušta uobičajeni obrazac širenja putem zaraženih štakora i buha te se može širiti kapljičnim putem, što mu omogućava ostavljanje razornih učinaka. ${ }^{1-2,5} \mathrm{Za}$ ovakav je tip karakteristično i to što su simptomi bolesti jači u toplim godišnjim dobima. Bolest i njezini simptomi naglo izbijaju u proljeće. Ljeto i rana jesen razdoblja su kada se bolest nekontrolirano širi i kada je smrtnost najveća, da bi se tijekom kasne jeseni intenzitet bolesti postupno smanjio i zimi gotovo potpuno nestao. ${ }^{1}$

„Crna smrt” u Europu je došla iz Azije, odakle su je Mongoli donijeli na obale Crnog mora gdje je svoje kolonije imala Genova koja je s njima bila u ratu. Tijekom opsade jedne đenovske tvrđave Mongoli su u nju ubacili zaražene leševe. Đenovljani su napustili tvrđavu i brodovima se uputili prema Italiji. Zbog toga što se to povlačenje odigravalo zimi nisu odmah bili vidljivi znakovi bolesti pa se raširila u lukama u kojima su zaraženi usput stajali: u Carigradu i na Siciliji. Jedna od galija uplovila je i u
Marseilles, a ostatak je stigao u Genovu. Tako su nastala četiri žarišta iz kojih se na proljeće bolest počela širiti prema unutrašnjosti i u nekoliko je valova do 1353. poharala gotovo cijeli kontinent..$^{1-2,4}$ Vremenski tijek i smjerovi širenja prikazani su na karti na slici 2.

Kada se govori o trenutačnom utjecaju ove epidemije, njega je s medicinskog stajališta vrlo lako uočiti. Kuga je za sobom ostavljala pustoš jer je smrtnost bila iznimno visoka, a tadašnja je medicina bila jednostavno nemoćna pred razmjerima epidemije. S povijesne strane gledano, zanimljivo je uočiti da su epidemijom bili zahvaćeni svi slojevi društva, čak i plemstvo ili pripadnici svećenstva koji su živjeli u povoljnijim uvjetima stanovanja, prehrane ili dostupnosti higijene negoli ostatak stanovništva. Pri tom je osobito kler pretrpio visoku smrtnost jer su crkve i samostani bili mjesta kamo se slijevao najveći broj ljudi tražeći pomoć, ali i gdje se najčešće pružala njega oboljelima. ${ }^{1}$ Posljedice toga bit će

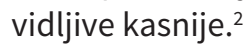

Postojalo je nekoliko područja koja su uspjela izbjeći kugu. Vlasti Milana u neposrednom susjedstvu Genove na prve glasine o izbijanju bolesti uvele su naoružane straže po svim putovima u okolici koje su imale zadatak spriječiti dolazak stranaca u grad. Slične su mjere nešto kasnije poduzete u Brugesu u današnjoj Belgiji. Epidemiju je kao pojedinačno najveće područje izbje-

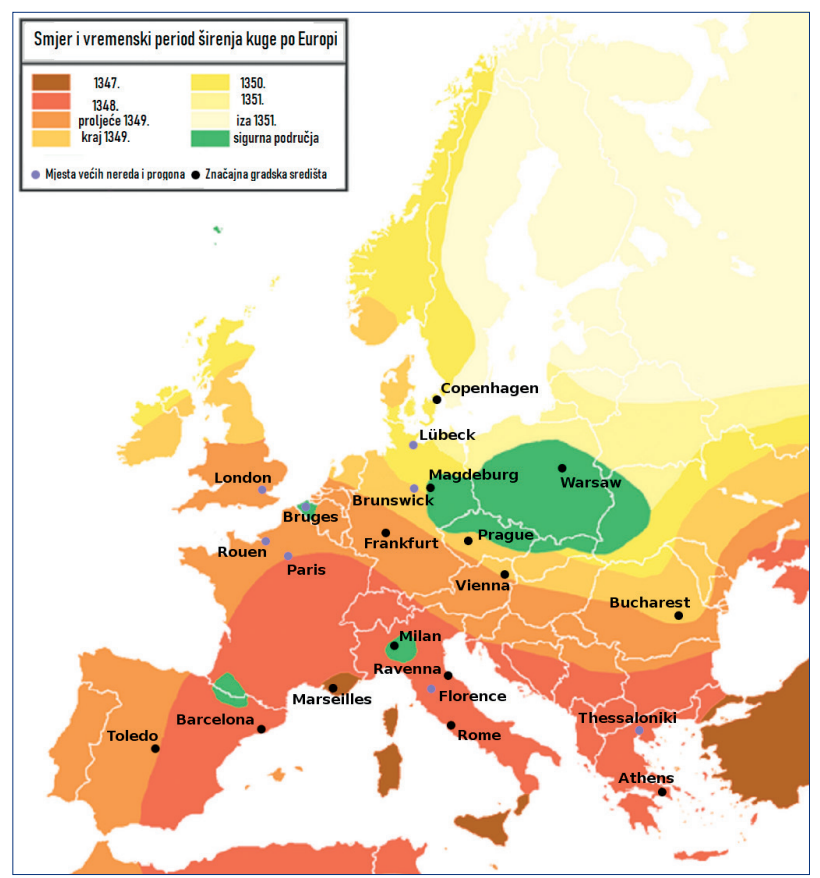

Slika 2. Smjer i vremenski period širenja kuge po Europi 
gla i Poljska. Međutim, suprotno očekivanjima, nitko od spomenutih nije imao neke znatnije prednosti u razdoblju kada se epidemija povukla. Odnosi između različitih europskih država ostali su više-manje isti kao i prije epidemije. Na taj se način ne može govoriti da je kuga promijenila tijek povijesti.

Dugoročno gledano, ipak je imala znatan utjecaj na povijest. Osim u umjetnosti, gdje je čestom temom u slikarstvu i književnosti, njezin utjecaj ponajprije opažamo u promjeni uvjeta stanovanja za preživjele. Nakon što se epidemija povukla, odjednom je drastično smanjen broj ljudi uživao obilje poljoprivrednih plodova pa se dio zemljišta mogao prenamijeniti za uzgoj stoke. To je dovelo do promjena u prehrambenim navikama. $\mathrm{U}$ gradnji nastamba sada se sve više počinje primjenjivati kamen, što će dugoročno dovesti do poboljšavanja sanitarnih prilika, iako valja naglasiti da ove promjene nisu u sve dijelove Europe stizale istim tempom. $\mathrm{Na}$ društvenoj strani promjene su zahvatile Crkvu. U njezinim je redovima drastično opao moral, a širili su se korupcija i nepotizam, što će u 16 . st. činiti pogodno tlo za širenje protestantske reformacije. ${ }^{3}$ Napokon, poučene milanskim primjerom, i druge će države uvesti praksu striktne zdravstvene kontrole pridošlica i javlja se sustav karantena. ${ }^{1}$

\section{Napoleonov pohod na Rusiju i tifus}

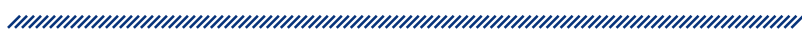

Napad koji je Napoleon Bonaparte na vrhuncu svoje moći 1812. poduzeo na Rusiju i njegov neslavni završetak spadaju vjerojatno $u$ jednu od najpoznatijih povijesnih epizoda, premda većina ljudi ima pogrešan stav o uzrocima Napoleonova poraza. Suprotno raširenoj verziji događaja, slom francuskih planova nije uslijedio zbog ruske zime. Napoleonovu propast uzrokovala je epidemija tifusa. ${ }^{1,8}$

Da nešto nije u redu s raširenom verzijom događaja može se uočiti već analizom grafa na slici 3. Iz njega je vidljivo da je tijekom napredovanja prema Moskvi francuska vojska (nazvana Velika Armija) izgubila više od dvije trećine ukupnog ljudstva. Dio je dezertirao, a dio je stradao u sporadičnim borbama s Rusima, međutim bila je riječ o manjem broju ukupnih gubitaka. U svakom slučaju, nitko od njih nije stradao od hladnoće. Zima je pogodila vojsku prilikom povlačenja iz Moskve, ali tada se već moglo govoriti o slomljenoj vojsci. Kako je do toga došlo?

Velika Armija bila je najveća vojna sila koju je Europa vidjela u svojoj dotadašnjoj povijesti. Procjene o njezinoj veličini variraju od 400000 do čak više od 600000 vojnika. Nitko nije imao iskustva u zapovijedanju tolikim brojem ljudi, kao ni u njihovu opremanju, transportu i

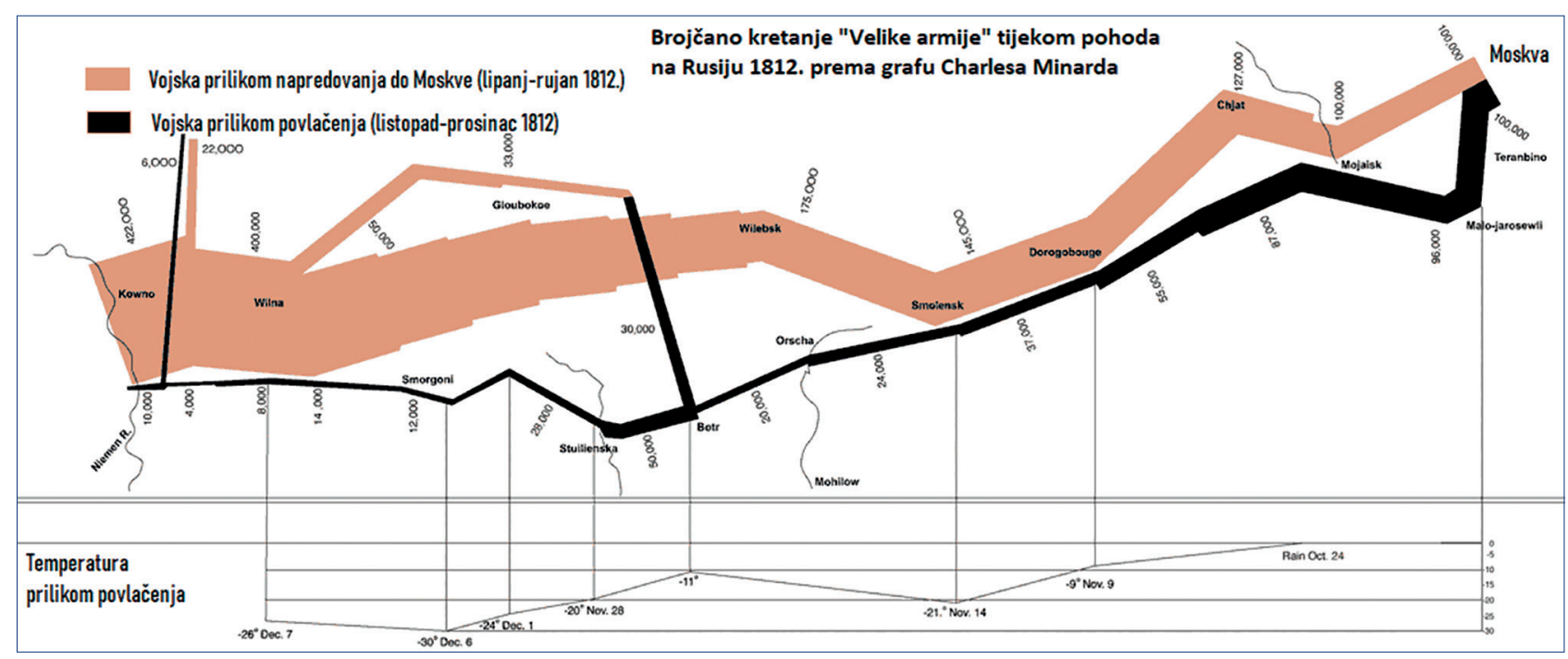

Slika 3. Graf koji prikazuje brojčano kretanje Napoleonove vojske tijekom pohoda na Moskvu i povlačenja natrag. Oko brojki ne postoji suglasje, moguće je da su bile i osjetno veće 
opskrbi. Ipak, do dolaska u Poljsku, koja je poslužila kao baza za napad, sve je više-manje funkcioniralo besprijekorno. Tadašnja francuska vojska bila je superiorna ostalim vojskama ne samo zbog Napoleonova zapovijedanja nego i zbog izvrsno razrađene logistike. Francuzi su imali organizirani transport namirnica i svježe vode, pokretljive bolnice s izučenim liječnicima, pa čak i prototip hitne pomoći u vidu brzih konjskih zaprega na kojima su bolničari ranjenicima smjesta mogli pružiti prvu pomoć. ${ }^{1}$ U Poljskoj i Rusiji Napoleon se susreo s lošom infrastrukturom, osobito cestama, što je razvuklo njegove jedinice i omelo opskrbu. Također, Rusi su primijenili taktiku spaljene zemlje, uništavajući sve na putu kojim su Francuzi morali proći. ${ }^{1,8}$ I meteorološke prilike bile su pomalo ekstremne. Francuze su najprije pratili dugotrajni i jaki pljuskovi, a zatim je slijedila jaka suša koja je jako snizila razinu vode u bunarima. U kombinaciji svega navedenoga drastično je opala disciplina i zakazalo je provođenje uobičajenih higijenskih postupaka kao što je prokuhavanje vode. Za neke druge, poput pranja i mijenjanja rublja, nije ni bilo uvjeta. Tako su se vojnici zarazili tifusom. S dijagnostičkog gledišta bilo bi zanimljivo utvrditi o kojemu je tipu bila riječ - trbušnom ili pjegavom, budući da sačuvani opisi govore u prilog $\mathrm{i}$ jednoj i drugoj varijanti. Loši higijenski uvjeti jako pogoduju širenju oba tipa bolesti. Trbušni se tifus lako širi dodirom, dok pjegavi prenose uši i ostali nametnici. ${ }^{8,9}$ Napoleon je pokušao doskočiti novonastaloj situaciji podizanjem dviju baza u Smolensku i Vilniusu koje su trebale poslužiti kao bolnice za prihvat oboljelih, ali i kao skladišta hrane i vojnih rezervi radi osiguravanja njegova napredovanja. ${ }^{1}$ Uza sve poteškoće, Francuzi su na kraju uspjeli osvojiti Moskvu. No budući da Rusi nisu pristajali na sklapanje primirja, uslijedilo je povlačenje. Upravo ovdje na scenu stupa utjecaj tifusa. Napoleon je imao plan povući se u jednu od dviju spomenutih baza, ondje provesti zimu, oporaviti svoju vojsku i dovesti pojačanja s kojima bi na proljeće nastavio rat. Međutim, u spomenutim se bazama tifus proširio u tolikoj mjeri da se raspao svaki sustav zapovijedanja i logistike. ${ }^{1} \mathrm{Ne}$ samo da Napoleon nije našao sigurno sklonište nego ni njegova smrznuta i izgladnjela vojska nije našla ikakve namirnice. To je predstavljalo konačan udarac.

Upravo ovdje jasno je vidljiv trenutačan utjecaj epidemije na povijest. Tifus je doista promijenio njezin tijek. Prilikom povlačenja Napoleon se, s drastično smanjenim brojem jedinica koje su $\mathrm{k}$ tome bile u vrlo lošem stanju, u jednom trenutku našao u naizgled bezizlaznoj situaciji okružen dvjema brojčano većim ruskim vojskama i rijekom na kojoj su bili porušeni mostovi. Usprkos svim poteškoćama, Francuzi su uspjeli izvršiti protunapad na jednu od njih i silom si prokrčiti put prema zapadu. ${ }^{1}$ Iz toga slijedi logična pretpostavka da bi Napoleon da epidemija tifusa nije slomila organizaciju njegove vojske imao mogućnost rat okončati svojom pobjedom.

Zbog određene vremenske blizine ovih događaja ponešto je nezahvalno procjenjivati dugoročne učinke ove epidemije tifusa. Zasigurno je onemogućila francusku prevlast na kontinentu, ali je, naravno, nemoguće procjenjivati kako bi izgledala kasnija europska povijest. Možda je najvažniji dugoročni učinak ove povijesne epizode spoznaja da određena znanja i tehnički stupanj razvoja nisu garancija uspješnog provođenja medicinske prevencije. Napoleon je posjedovao sve navedeno, ali se našao u situaciji gdje to nije mogao provesti. Stoga je njegov pohod na Rusiju opomena koja može pomoći u suočavanju s nekim medicinskim izazovima koji čovječanstvo očekuju u budućnosti.

\section{Usporedna analiza}

\subsection{Doseg epidemija}

Na osnovi tri opisana primjera sasvim je jasno kako bolest može utjecati na povijest. Usporedna analiza stoga bi trebala ukazati na sličnosti i razlike. Zajednička je svim trima slučajevima epidemijska narav bolesti. Zaraza je izbijala nenadano i brzo se širila uz neprestano povećavanje broja oboljelih. U sva tri slučaja ipak je nemoguće utvrditi o kolikom je točno postotku ukupno izložene populacije bila riječ. Po pitanju strukture oboljelih svaki pokazuje određenu osobitost. Kod epidemija koje su poharale stanovništvo Novoga svijeta i Europe prilikom „crne smrti” bila je riječ o masovnim epidemijama koje nisu bile geografski ili socijalno izolirane. U oba slučaja postoje iznimke. U prvome je bila riječ o europskim (konkretno španjolskim) kolonizatorima koji su na određeni način bili i izvorom epidemija, a sami su posjedovali imunitet na bolesti koje su se širile među Indijancima. Prilikom epidemije kuge neka su područja izbjegla zarazu zahvaljujući prometnoj izoliranosti ili pravodobno poduzetim mjerama predostrožnosti. Francuska Velika Armija s druge strane predstavlja primjer izolirane (premda iznimno brojne) skupine koja je također u ogromnom postotku bila izložena epidemiji, 
ali je u odnosu na ukupno stanovništvo prostora kojim se kretala - a koje je izbjeglo zarazu - predstavljala manjinu. Na identičan se način može analizirati i geografski obrazac. U prva dva slučaja epidemije su zahvatile najšire moguće područje, dok se u slučaju tifusa epidemija kretala istim smjerom kao francuska vojska. lako je relativno malen broj francuskih vojnika uspio izaći iz Rusije, ipak su prilikom povlačenja kroz Poljsku i Njemačku proširili bolest i ondje. ${ }^{1}$ Doduše, nije poznato da je epidemija dosegla ikakve šire razmjere.

\subsection{Trajanje}

Osim geografskog i demografskog, treba primijeniti i kriterij trajanja. U slučaju američkih Indijanaca bila je riječ o izbijanju nekoliko epidemija koje su tijekom 16. st. nanijele goleme demografske gubitke. Svaka je od njih ipak bila vremenski gledano ograničenog trajanja: prva 1519. i 1520., a zatim od 1545. do 1548. te od 1576. do 1578. Ova nas relativna kratkoća navodi na zaključak kako je doseg epidemija (odnosno broj zaraženih i umrlih) bio iznimno velik, odnosno da epidemije nisu prestajale zbog nekih poduzetih mjera, nego zbog toga što se bolest više nije imala kamo širiti. Period „crne smrti" trajao je nešto duže, od 1347. do 1353., s tim da valja napomenuti kako se epidemija širila postupno slijedeći vremenski obrazac širenja u proljeće i ljeto (a smirivanja u jesen i zimu) te se geografski obično širila iz smjera primorja prema kopnu te s juga kontinenta prema sjeveru te kasnije istoku. Na taj bi način zapravo neko područje bilo izloženo vrhuncu epidemije također samo tijekom jedne sezone, s tim da je kuga otada bila neprestano prisutna u Europi sve do 19. st., iako nikada više nije dosegnula razmjere „crne smrti”. ${ }^{1}$ Napoleonova je vojska od tifusa patila u maksimalnom rasponu od oko pet mjeseci, tj. od kraja lipnja, kada se okupila u Poljskoj, pa do početka prosinca, kada su i posljednji francuski vojnici napustili Rusiju.

\subsection{Broj oboljelih i umrlih}

Posljednji je čimbenik pitanje ukupnog broja žrtava. To se može promatrati kroz prizmu apsolutnih brojki, ali je za promatranje utjecaja na povijest važnije pitanje koliki su udio žrtve činile u ukupnoj populaciji. U svakom od tri slučaja teško je iznijeti precizne brojke, tako da procjene valja uzeti s određenim oprezom. Okvirni izračun za smrtnost Indijanaca na području današnjeg Meksika iznosio bi oko $30 \%$ za epidemiju velikih boginja 1519. i 1520., čak $80 \%$ za epidemiju od 1545 . do 1548. te napokon $50 \%$ za posljednji period završen 1578 . godine. ${ }^{2}$ Sve ovo vidljivo je i iz grafa na slici 1. Što se tiče „crne smrti”, procjene su još teže. Naime, iz tog je perioda sačuvano dosta kronika čiji su pisci kao svjedoci događaja u kojima su izgubili svoje najbliže bili skloni pretjerivanju, kao i pod dojmom da je riječ o Božjoj kazni, pa često bilježe kako je preživio ${ }^{3}$ tek svaki deseti stanovnik, što bi predstavljalo gubitak od čak $90 \%$ stanovništva, što je ipak nevjerojatno. Realnije procjene kreću se u rasponu od 40 do $60 \%$ europskog stanovništva koje je podleglo kugi, s tim da su vjerojatno postojale znatne regionalne razlike. Primjerice, u slučaju Italije smrtnost je bila kudikamo veća u gušće naseljenim gradovima negoli u ipak rjeđe naseljenim seoskim područjima. Također, opravdano je pretpostaviti kako je smrtnost ipak bila manja u sjevernijim krajevima već i zbog klimatskih prilika s obzirom na to da su ondje periodi toplog vremena trajali kraće pa je i širenje bolesti imalo kratkotrajniji doseg. Što se tiče Velike Armije, vidjeli smo da procjene njezine brojnosti drastično variraju (od 400000 do 600000 , pa i više), premda se uzima da se do kraja 1812. iz Rusije vratilo oko 22000 do 40000 vojnika. To bi ukupne gubitke dovelo do zapanjujućih razmjera od 90 do čak $95 \%$. Međutim, bilo bi prejednostavno cijelu razliku svesti na smrtno stradale. Dio vojnika činili su Napoleonovi nevoljni njemački saveznici iz Pruske i Austrije koji su još tijekom pohoda promijenili stranu i bez većih se gubitaka izvukli iz Rusije. Nadalje, dio vojnika poginuo je u više bitaka koje su vođene protiv ruske vojske. Ipak, najteže je procijeniti koliki je broj vojnika dezertirao, koliki bio zarobljen, a koliki je podlegao gladi ili hladnoći prilikom povlačenja. Neke procjene govore o 300000 vojnika koji su bili žrtve tifusa, ${ }^{8}$ ali ih ipak treba uzeti uz određeni oprez. Postoje podaci kako je u Rusiji nakon pohoda ostalo oko 100000 Francuza koji su se zaposlili kao učitelji francuskog jezika i odgojitelji ili stupili u druga zanimanja, pa čak i u rusku vojsku. Točan broj i udio smrtnih slučajeva koje je izravno izazvao tifus nije moguće utvrditi već i stoga što, za razliku od bolesti u druga dva slučaja, on ima osjetno nižu stopu smrtnosti, tj. postoji određena mogućnost izlječenja. Sva ova četiri parametra sažeto su prikazana u tablici 1.

\subsection{Utjecaj epidemija na povijest}

Sljedeći je istraživački problem pitanje utjecaja bolesti na tijek povijesti. Njega smo podijelili na trenutačan - $u$ smislu da se njegovi učinci odmah jasno vide, odnosno posredan - takav gdje se posljedice neke epidemije uočavaju kasnije, odnosno kada već prođe. Drugo pitanje utjecaja bilo je ono o tome mijenja li bolest tijek povijesti, odnosno može li se pretpostaviti da bi tijek zbivanja 
bio drastično drugačiji da nije došlo do izbijanja epidemija. Kada svaki od tri primjera provučemo kroz ovakvo sito ponovno uočavamo neke sličnosti, kao i razlike sumirane u tablici 2.

Slučaj epidemija u Meksiku pokazuje trenutačan i neposredan utjecaj u slučaju prve epidemije čije se izbijanje poklopilo s dolaskom španjolskih konkvistadora kojima je bolest otvorila put ka relativno jednostavnom i brzom osvajanju golemih prostora. Preostale dvije epidemije dovele su do drastičnog opadanja broja već pokorenog stanovništva, zbog čega se otvorila potreba za većim doseljavanjem europskog stanovništva, kao i za dovođenjem crnačkih robova iz Afrike ${ }^{1}$ (iako nisu bili toliko prisutni u samom Meksiku koliko u nekim drugim krajevima koje su osvojili Španjolci i Portugalci). Ova se praksa kasnije proširila i na sjeverni dio kontinenta.
Time su jasno uočljiva oba vida utjecaja na povijest, trenutačan i posredan. Procjena je li bolest promijenila povijest svakako je teža. Može se pretpostaviti da bi Španjolci koji su u pogledu naoružanja bili na kudikamo višem stupnju razvoja svejedno na kraju ostvarili svoju namjeru i osvojili željena područja. Međutim, vjerojatno bi cijeli taj proces trajao znatno dulje i uz snažniji otpor. O pitanju širenja prakse robovlasništva može se nagađati, no može se pretpostaviti da bi većim dijelom bilo oslonjeno na porobljavanje Indijanaca, odnosno da bi udio crnačkog stanovništva danas u nekim državama poput SAD-a, Kolumbije ili Brazila bio osjetno manji.

"Crna smrt" također je proizvela veliku smrtnost, ali se ovo nije osjetilo na političkom planu. Čak i ona područja koja su izbjegla kugu, kao primjerice Milano ili osobito Poljska, nisu nakon prolaska epidemije ostvarila veću

\begin{tabular}{|c|c|c|c|}
\hline & "Crna smrt" & Epidemije u Americi & $\begin{array}{c}\text { Tifus u Napoleonovoj } \\
\text { vojsci }\end{array}$ \\
\hline Geografska raširenost & Europa, sjeverna Afrika, Azija & Srednja Amerika & $\begin{array}{l}\text { Prostor kretanja vojske u } \\
\text { Rusiji }\end{array}$ \\
\hline \multirow{3}{*}{ Vremensko trajanje } & \multirow{3}{*}{ 1347.-1353. } & 1519.-1520. & \multirow{3}{*}{ lipanj-prosinac 1812.} \\
\hline & & $1545 .-1548$ & \\
\hline & & 1576.-1578. & \\
\hline $\begin{array}{l}\text { Stupanj izloženosti/ } \\
\text { zaraženosti }\end{array}$ & \multicolumn{2}{|c|}{ vjerojatno identičan onomu smrtnosti } & $\begin{array}{c}\text { cjelokupna francuska vojska/ } \\
\text { upitan broj zaraženih }\end{array}$ \\
\hline \multirow{3}{*}{ Stopa smrtnosti } & \multirow{3}{*}{$\begin{array}{l}40-60 \% \text { (uz osjetne } \\
\text { geografske razlike). }\end{array}$} & $30 \%$ & \multirow{3}{*}{$\begin{array}{c}50 \% \text { (prema nepouzdanim } \\
\text { procjenama) }\end{array}$} \\
\hline & & $80 \%$ & \\
\hline & & $50 \%$ & \\
\hline \multicolumn{4}{|c|}{ Tablica 2. Utjecaj bolesti na povijest } \\
\hline & "Crna smrt" & Epidemije u Americi & $\begin{array}{c}\text { Tifus u Napoleonovoj } \\
\text { vojsci }\end{array}$ \\
\hline \multirow{3}{*}{$\begin{array}{l}\text { Neposredan utjecaj na } \\
\text { povijest }\end{array}$} & \multirow{3}{*}{$\begin{array}{l}\text { visoka smrtnost; progon } \\
\text { Židova }\end{array}$} & $\begin{array}{c}\text { Olakšavanje španjolskog } \\
\text { osvajanja }\end{array}$ & \multirow{3}{*}{$\begin{array}{c}\text { slom sustava logistike - } \\
\text { direktna veza s francuskim } \\
\text { porazom }\end{array}$} \\
\hline & & $(-)$ & \\
\hline & & $(-)$ & \\
\hline \multirow{3}{*}{ Posredan utjecaj na povijest } & \multirow{3}{*}{$\begin{array}{c}\text { Promjene u sklopu društvenih } \\
\text { vrijednosti; kasnije izbijanje } \\
\text { Reformacije }\end{array}$} & $(-)$ & \multirow{3}{*}{$\begin{array}{l}\text { Prestanak francuske } \\
\text { dominacije. Postupan porast } \\
\text { britanske i kasnije američke } \\
\text { moći i utjecaja na društvo. }\end{array}$} \\
\hline & & $\begin{array}{c}\text { Gubitak radne snage dovodi } \\
\text { do obnavljanja robovlasničke } \\
\text { prakse }\end{array}$ & \\
\hline & & v. gore & \\
\hline \multirow{3}{*}{ Bolest mijenja povijest (+/-) } & \multirow{3}{*}{$\begin{array}{l}\text { neposredno }(-) \\
\text { posredno }(+)\end{array}$} & $(-)$ & \multirow{3}{*}{$(+)$} \\
\hline & & $(+)$ & \\
\hline & & $(+)$ & \\
\hline
\end{tabular}


prednost u odnosu na zaražene susjede. Trenutačan utjecaj koji je kuga imala na povijest predstavlja mračna epizoda progona Židova koji su često bili proglašeni kolektivnim krivcima za izbijanje epidemije, premda su joj bili jednako izloženi. S druge strane, posredni utjecaj jasno se zapaža na pitanjima povezanima sa socijalnim uvjetima življenja: od porasta svijesti o važnosti higijenskih i sanitarnih uvjeta, preko općenitog poboljšavanja kvalitete života do preispitivanja dotadašnjeg poimanja društvene uloge nekih institucija kao što je bila Crkva. To će dva stoljeća kasnije dovesti do izbijanja protestantske reformacije. ${ }^{1,2}$ Da se ovi posredni utjecaji mogu osjetiti i više od pola tisućljeća kasnije svjedoči jedan zastrašujući primjer iz 20. st. Naime, budući da je Poljska izbjegla kugu, ondje su utočište potražili i našli brojni Židovi koje se u ostatku Europe često smatralo glavnim krivcima za epidemiju. Kada je Adolf Hitler zauzeo Poljsku, svoju je ubilačku politiku usmjerio na uništavanje Židova i polovicu ukupnih žrtava holokausta (3 od 6 milijuna) činili su upravo poljski Židovi. Naravno, nije kuga izazvala Hitlerov antisemitizam, ali budući da se Poljska najdulje nalazila pod nacističkom okupacijom, to je uništavanje Židova ondje imalo iznimno poguban učinak.

Napoleonov pohod na Rusiju i utjecaj koji je bolest imala zbog vremenske su blizine najlakši za analizu. Premda je smrtnost od tifusa sigurno činila osjetno manji udio negoli u slučaju ostalih analiziranih primjera, njegov je utjecaj možda bio i najneposredniji. Naime, do izbijanja i širenja epidemije došlo je zbog logističkih poteškoća koje su onda uslijed bolesti dovele do potpunog sloma sustava opskrbe. To je najbolje vidljivo na primjeru dviju baza (u Vilniusu i Smolensku) koje su zbog nemogućnosti nošenja s velikim brojem zaraženih izgubile svoju svrhu. Umjesto da posluže Napoleonu da u njima u sigurnosti provede zimu, razvoj situacije doveo je do toga da se iscrpljena i slabo opskrbljena vojska u povlačenju morala suočiti s hladnoćom i općom nestašicom, što je sve dovelo do potpunog sloma. Kada se pak uzme u obzir da Rusi nisu uspjeli u potpunosti spriječiti da se sam Napoleon i malobrojan dio vojnika ipak uspiju izvući te da su to dobrim dijelom postigli snagom oružja, jasno je da bi bez izbijanja bolesti Francuzi imali kudikamo veće šanse za uspješno vođenje rata. Uostalom, posljedice velikih gubitaka u Rusiji na vidjelo su izašle sljedeće godine, kada se Napoleon borio protiv široke koalicije svojih protivnika. Njegova nova vojska bila je sastavljena od ipak neiskusnih mladića, ali je i takva nanijela nekoliko poraza protivnicima prije nego što je konačno potjerana u Francusku, a Napoleon bio prisiljen na povlačenje s prijestolja.

\section{Zaključak}

Cjelokupna ljudska povijest obilježena je i neprestanom prisutnošću bolesti. Njezin je utjecaj lako uočiti u sferama kao što su uvjeti svakodnevnog života ili u sklopu samog povijesnog razvoja medicine i s njom povezanih znanosti. U određenim povijesnim trenucima može se razabrati kako je bolest na određeni način nadišla tu ulogu dijela svakodnevice i imala utjecaj na sam tijek povijesti. Pri tome se jasno mogu razlikovati neposredan utjecaj koji je nastao kao trenutačna posljedica izravnog doticaja s bolešću te s druge strane posredan utjecaj, odnosno takav koji se zapaža na duljem periodu, a njegove posljedice obično osjećaju oni koji sami nisu bili u izravnom doticaju s bolešću. Napokon, uzmemo li u obzir da je biološko ratovanje zabilježeno još u starom vijeku, 1500 godina pr. Kr., kao i opisani slučaj kada su Mongoli koristili zaražene leševe i time zapravo izravno izazvali kugu među Đenovljanima, potvrđuje se da su ljudi već više tisuća godina svjesni pogubne strane utjecaja bolesti na povijest. ${ }^{10}$

O utjecaju bolesti na povijest može se govoriti na dvije razine: a) kroz pojavu takvog tipa bolesti koji zahvaća veće skupine stanovništva, čime je šira društvena zajednica neposredno izložena njezinu djelovanju odnosno b) kada bolest zahvati nekog pojedinca - primjerice nekog vladara - koji ima mogućnost utjecaja na spomenutu širu društvenu zajednicu te tako bolest svoj utjecaj ostvaruje posredno. Budući da u drugom slučaju može biti riječ o psihičkim bolestima pa se često govori o „ludim" vladarima, ovom prilikom usmjerili smo se na primjere nekoliko poznatih epidemija, dok će bolest pojedinca i njezin utjecaj na povijest predstavljali temu nekog budućeg rada.

U analizi triju epidemija uočljivo je kako mogu biti širih razmjera, odnosno takve da zahvaćaju sve slojeve stanovništva, ali i na neki način izolirane, odnosno takve da zahvate samo određenu skupinu, dok populacija izvan nje u najvećoj mjeri ostaje pošteđena. U svakom se od slučajeva u različitim omjerima, ali ipak jasno pokazuju primjeri neposrednog utjecaja koji bolest ima na povijest, kao i onog posrednog, tj. kako je već rečeno, dugotrajnijeg utjecaja. Dosadašnja literatura, neovisno o tome je li napisana iz isključivo medicinskog ili nešto šireg povijesnog kuta gledanja, pa tako i ona upotrijebljena ovom prilikom, nužno navodi na zaključak da bolest utječe na povijest. U slučaju ovdje opisanih 
epidemija taj se utjecaj dosad opažao primarno na vremenskoj razini, što je opisano i u prethodnom dijelu.

Određena novost koju ovaj rad pokušava donijeti jest i pomalo nezahvalna procjena je li utjecaj neke bolesti bio takav da je promijenio tijek povijesti koja bi, da nije bilo određene epidemije, izgledala potpuno drugačije. Oba su se dosadašnja pristupa istraživanja, „usko” medicinski i „usko” povjesničarski, ovog pitanja doticali samo usputno ili ga u potpunosti zaobilazili. Kako je već rečeno, specijalizirani medicinski radovi usmjereniji su na preciznu dijagnozu i etiologiju neke bolesti, dok se povjesničari najčešće ne upuštaju u procjene „što bi bilo, kad bi bilo". Takav je pristup vidljiv i u upotrijebljenoj literaturi. Postoji dovoljno naznaka da je utjecaj bolesti na povijest ponekad bio takav i da ju je mijenjao, ali se spomenuto više iznosi kao hipoteza nego kao zaključak.

Hipoteza da povijest uslijed djelovanja bolesti može poći drugačijim tokom može se potvrditi na primjeru Napoleonova pohoda na Rusiju. Epidemija tifusa koja je zahvatila njegovu vojsku imala je presudan utjecaj na njezino borbeno stanje, ali i na Napoleonov plan ratovanja, jer je onemogućila uspostavu baza u kojima bi vojska u sigurnosti provela zimski period. Na taj je način bolest doista promijenila tijek povijesti jer je opravdano pretpostaviti da bi Francuzi ili uspješno porazili Rusiju ili sljedeće godine veliku koaliciju, budući da su do tada bili dominantna sila.

Ono što ovom prilikom posebno valja istaknuti jest razlikovanje ova dva vida utjecaja. Da bolest u vidu epidemija utječe na povijest, vjerojatno ne treba posebno naglašavati, ali je doseg tog utjecaja obično toliko širok da se na koncu može govoriti kako je bolest neke stvari ubrzala ili usporila, ali ne i promijenila. Drugim riječima, bolest uvijek utječe na povijest, ali je samo ponekad mijenja (isticanja autorice). Čak i kada pretpostavimo ovu drugu hipotezu i kada imamo dovoljno argumenata da bismo je podržali, opet moramo biti vrlo oprezni. Analizirani slučaj Napoleonova pohoda pruža dovoljno argumenata za zaključak da je tifus promijenio tijek povijesti. Ipak, ne smijemo bježati od usporedbe ovog pohoda s onim nacističke Njemačke više od stoljeća kasnije. Njemačka se vojska nije suočila s bolešću, u Rusiji (tada SSSR-u) se zadržala i nešto dulje, ali s druge strane nije uspjela osvojiti Moskvu. Ova kratka usporedba s jedne strane ukazuje na to koliko je teško nagađati bi li neki povijesni događaj tekao drugačije da nije bilo ove ili one okolnosti, ali s druge samo potvrđuje koliko je u promatranju društva oko nas potrebno rabiti metode i rezultate više različitih znanstvenih disciplina, odnosno da medicina i povijest mogu mnogo toga naučiti jedna od druge.
Slučaj francusko-ruskog rata 1812. važno je istaknuti zbog još jedne stvari. Naime, do danas je uvriježeno mišljenje da je Napoleona porazila ruska zima i činjenica da je bolest tifus bila onaj faktor koji je slomio disciplinu i spremnost francuske vojske. U sva tri slučaja epidemije su izbile i zbog toga što ih nitko nije očekivao, a na početku se nije s njima znao ni nositi. U slučaju kuge može se u obzir uzeti objektivna okolnost da je bila riječ o mutaciji virusa kuge u bubonski tip kojemu nije bilo lijeka, a brzina širenja zaraze nadilazila je mogućnosti srednjovjekovnog društva da je spriječi. Iste objektivne okolnosti valja imati na umu i kada se govori o epidemijama koje su poharale američke Indijance. U barem jednom od slučajeva bila je riječ o bolesti s kojom se zaraženi nikada ranije nisu susreli pa stoga nisu imali nikakav imunitet. Primjer Napoleonova susreta s tifusom s druge strane može i mora poslužiti kao opomena. Francuska vojska njegovala je higijenske i medicinske standarde koji su u ono doba bili na zavidnoj razini. Međutim, kada se našla u okruženju i situaciji u kojoj ih nije bila u stanju primjenjivati na odgovarajući način, to ju je dovelo do toga da bude izložena epidemiji i svim njezinim negativnim posljedicama, koje su na kraju skršile njezinu borbenu moć.

Danas nam se može činiti kako je vrijeme velikih epidemija iza nas, odnosno da su mogućnosti medicinske prevencije svakog dana sve razvijenije. Svaki od opisanih slučajeva može poslužiti kao primjer određenih rizika koji postoje i dalje. "Crna smrt” svjedoči da i poznate bolesti, a u srednjem vijeku kuga je bila dobro poznata, mogu mutacijom dobiti oblik koji se može pokazati razornim. U nedavnoj prošlosti takav je primjer tzv. španjolska gripa, kada se ova sezonska bolest pojavila u pogibeljnom obliku. Epidemije američkih Indijanaca pružaju primjer pojave novih bolesti. lako se čini da je današnji svijet postao globalno selo, osobito zbog mogućnosti brzog putovanja, ipak i ovdje postoje relativno nedavni primjeri kada su neke bolesti (npr. ebola) prešle iz jednog dijela svijeta u drugi, srećom, ne izazvavši epidemiju. Napokon, primjer susreta Napoleonove vojske s tifusom pokazuje da se medicinske standarde, ma kako oni bili visoki, neprestano mora prilagođavati tako da mogućnost njihove adekvatne primjene uvijek bude na iznimno visokoj razini. Ako je povijest doista učiteljica života, medicina sigurno može biti jedna od njezinih najboljih učenica. 


\section{Referencije}

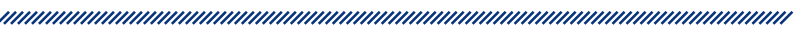

1. Cartwright FF, Biddis M. Bolest i povijest. Lucija Horvat, prevoditeljica. Zagreb: Naklada Ljevak; 2006. 270 p.

2. Ziegler P. The Black Death. Reprint edition. New YorkLondon-Toronto-Sydney-New Delhi-Auckland: Harper Perennial - Modern Classics; 2009. 319 p.

3. Acuna-Soto R, Stahle DW, Cleaveland MK, Therrell MD. Megadrought and Megadeath in $16^{\text {th }}$ Century Mexico. Emerging Infectious Diseases [internet]. 2002 Apr; 8(4): 360-362. Dostupno na: https://dx.doi.org/10.3201/ eid0804.010175 (pristupljeno 10.8.2018.).

4. Todorović K. Kuga. U: Šercer A. Grmek MD. Medicinska enciklopedija sv. 4. Zagreb: Jugoslavenski leksikografski zavod; 1969. 187-194.

5. Cvetnić Ž. Kuga - bolest koja je promijenila svijet, I. dio, Veterinarska stanica. 2014; 45(2): 85-95.

6. Cvetnić Ž, Šoštarić B. Kuga - bolest koja je promijenila svijet, II. dio, Veterinarska stanica. 2014; 45(3): 163-173.

7. Cvetnić Ž. Kuga - bolest koja je promijenila svijet, III. dio, Veterinarska stanica. 2014; 45(4): 268-278.

8. Conlon JM. The Historical Impact of Epidemic Typhus [internet]. Bozeman (MT): Montana State University, Entomology Group - Insects, Disease and History; 2007. Dostupno na: http://www.montana.edu/historybug/documents/TYPHUS-Conlon.pdf (pristupljeno 10.8.2018.).

9. Todorović K, Nikolić M. Tifus. U: Grmek MD. Medicinska enciklopedija, sv. 6. Zagreb: Jugoslavenski leksikografski zavod; 1970. 233-238.

10. Barras V, Greub G. History of biological warfare and bioterrorism. Clinical Microbiology and Infection [internet]. 2014 Jun; 20(6): 497-502. Dostupno na: https://www. clinicalmicrobiologyandinfection.com/article/S1198743X(14)64174-4/pdf (pristupljeno 14.8.2018.). 


\section{THE IMPACT OF THE DISEASE ON HISTORY - AN EXAMPLE OF EPIDEMICS}

1 Jelena Barišić

1 University Hospital Centre Zagreb - Surgery Clinic: Department of Traumatology

\section{Summary}

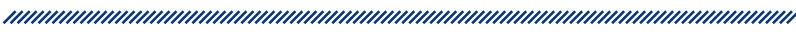

It is possible to study the history of the disease in many different ways. The research can stay within strictly medical frames and it can focus itself on the type of the disease, on questions of its prevention, on methods of its treatment etc. Nevertheless, since its consequences are recognizable on a broader social level, a disease isn't merely a medical phenomenon. Therefore it is very important to understand in which way a disease affects the history.

This paper intends to present the examples of three epidemics which in different historical periods plagued various geographical regions. Influence of the disease is analyzed on three levels: duration of each of the epidemics; geographical prevalence and hypothesis whether some disease has changed the course of the history.

Keywords: history, epidemic, bubonic plague, typhus, smallpox, Napoleon 